\title{
La inconstitucionalidad de la ley a la luz de la jurisprudencia del Tribunal Constitucional
}

\author{
Cristian Román CoRdero \\ Universidad de Chile, Chile
}

El propósito del presente trabajo es exponer, en términos muy sintéticos, la práctica jurisprudencial del Tribunal Constitucional en relación a su atribución consultada en el artículo 93 número 7 de la Constitución, esto es, resolver la inconstitucionalidad de un precepto legal declarado inaplicable.

\section{Generalidades sobre la atribución del Tribunal Constitucional de resolver la inconstitucionalidad de un precepto legal}

La inconstitucionalidad de la ley se encuentra regulada tanto en la Constitución como en la Ley 17.997 Orgánica Constitucional del Tribunal Constitucional.

En la Constitución: a) el artículo 93 número 7 establece como atribución del Tribunal Constitucional el «resolver por la mayoría de los cuatro quintos de sus integrantes en ejercicio, la inconstitucionalidad de un precepto legal declarado inaplicable en conformidad a lo dispuesto en el numeral anterior»; b) el artículo 93 inciso undécimo precisa que «habrá acción pública para requerir al Tribunal la declaración de inconstitucionalidad, sin perjuicio de la facultad de éste para declararla de oficio. Corresponderá a la ley orgánica constitucional respectiva establecer los requisitos de admisibilidad, en el caso de que se ejerza la acción pública, como asimismo regular el procedimiento que deberá seguirse para actuar de oficio»; y c) el artículo 94 inciso tercero dispone que «el precepto declarado inconstitucional en conformidad a lo dispuesto en los numerales 2, 407 del artículo 93, se entenderá derogado desde la publicación en el Diario Oficial de la sentencia que acoja el reclamo, la que no producirá efecto retroactivo».

En la LOCTC: en su título II, párrafo 7, artículos 93 a 108.

De su regulación (constitucional y legal), se coligen sus notas características: a) es un control de constitucionalidad de la ley de carácter represivo y abstracto; b) solo procede respecto de un precepto legal que previamente haya sido declarado inaplicable; c) la declaración de inconstitucionalidad de un precepto legal solo se puede fundar en 
la contravención a la Constitución en la que se fundó la sentencia de inaplicabilidad que le sirve de antecedente. En efecto, conforme al artículo 101 de la LOCTC, ${ }^{1}$ «la declaración de inconstitucionalidad de las normas legales cuestionadas deberá fundarse únicamente en la infracción de el o los preceptos constitucionales que fueron considerados transgredidos por la sentencia previa de inaplicabilidad que le sirve de sustento"; d) el proceso respectivo puede iniciarse por acción popular o de oficio; e) la declaración de inconstitucionalidad de la ley requiere de un quórum de aprobación de 4/5 de los miembros en ejercicio del Tribunal Constitucional; f) la sentencia estimatoria, una vez publicada en el Diario Oficial, deroga, hacia futuro, el precepto legal. Se trata, conforme se observa, de una derogación sui generis que obedece no a razones de mérito sino a la inconstitucionalidad declarada; y g) produce efectos erga omnes.

\section{Sentencias del Tribunal Constitucional relativas a su atribución de resolver la inconstitucionalidad de un precepto legal}

Hasta la fecha, el Tribunal Constitucional ha dictado doce sentencias en ejercicio de esta competencia. Solo cuatro de ellas son estimatorias, la última de las cuales data de 2010. Dichas sentencias son las que figuran en el cuadro 1.

Adviértase en el cuadro 1, muy especialmente, que desde hace ya siete años (20102017) el Tribunal Constitucional no ha dictado sentencia de inconstitucionalidad de un precepto legal, lo cual contrasta con el periodo anterior a éste (2006-2010), en el que lo había hecho con cierta habitualidad (cuatro oportunidades). Estimo que lo anterior se explica por al menos dos razones: a) la adecuación de la LOCTC al texto de la Constitución modificada por la Reforma Constitucional del año 2005 (Ley 20.050), realizada a través de la Ley 20.381, publicada el 18 de octubre de 2009; y b) la consolidación de la jurisprudencia del Tribunal Constitucional en relación al ejercicio de esta atribución, de la cual es posible reconocer claros criterios, los que analizo a continuación.

\section{Sentencias del Tribunal Constitucional relativas a su atribución de resolver la inconstitucionalidad de un precepto legal: criterios jurisprudenciales}

Revisada la jurisprudencia del Tribunal Constitucional en relación a su atribución de resolver la inconstitucionalidad de un precepto legal, conforme a lo dispuesto en el artículo 93 número 7, de la Constitución, he podido reconocer al menos dieciséis criterios jurisprudenciales, a saber:

1. En correspondencia con ello, el artículo 97 de la LOCTC establece: «Procederá declarar la inadmisibilidad de la cuestión de inconstitucionalidad promovida mediante acción pública, en los siguientes casos: 1) cuando no exista sentencia previa que haya declarado la inaplicabilidad del precepto legal impugnado, y 2) cuando la cuestión se funde en un vicio de inconstitucionalidad distinto del que motivó la declaración de inaplicabilidad del precepto impugnado». 


\section{Cuadro 1}

\begin{tabular}{|c|c|c|c|}
\hline Fecha & Rol & Carátula & Resolución \\
\hline 08-03-2016 & $2800-15$ & $\begin{array}{l}\text { Requerimiento de inconstitucionalidad presentado por Pablo Contardo Opitz } \\
\text { respecto del inciso primero del artículo del } 5 \text { de la Ley } 18.900 \text {, en la frase } \\
\text { que indica. }\end{array}$ & Rechazado \\
\hline $21-03-2013$ & 2081-11 & $\begin{array}{l}\text { Requerimiento de inconstitucionalidad presentado por Nel Greeven Bobadi- } \\
\text { Ila respecto del artículo } 206 \text { del Código Civil. }\end{array}$ & Rechazado \\
\hline 24-05-2011 & $1723-10$ & $\begin{array}{l}\text { Proceso de inconstitucionalidad iniciado de oficio por el Tribunal Constitucio- } \\
\text { nal en relación al artículo } 2.331 \text { del Código Civil. }\end{array}$ & Rechazado \\
\hline $06-08-2010$ & $1710-10$ & $\begin{array}{l}\text { Proceso iniciado de oficio para decidir sobre la constitucionalidad del artículo } \\
38 \text { ter de la Ley de Isapres y cuya sentencia se publicó en el Diario Oficial el } 9 \\
\text { de agosto de } 2010 .\end{array}$ & Acogido \\
\hline $31-12-2009$ & $1444-09$ & $\begin{array}{l}\text { Requerimiento de constitucionalidad de los diputados María Antonieta Saa, } \\
\text { Enrique Accorsi y Ramón Farías respecto de la Tabla de Factores contemplada } \\
\text { en el artículo } 38 \text { TER de la Ley 18.933, de Isapres, que autoriza a éstas para } \\
\text { modificar unilateralmente el precio de los planes — contratos—- de salud, } \\
\text { norma que actualmente corresponde al artículo } 199 \text { del DFL 1, de Salud, de } \\
2005 .\end{array}$ & Inadmisible \\
\hline $25-08-2009$ & $1450-09$ & $\begin{array}{l}\text { Requerimiento de inconstitucionalidad de Mario González Rifo, Presidente } \\
\text { de la Asociación Gremial denominada Comando de Exonerados Políticos de } \\
\text { las Fuerzas Armadas y de Orden, y en su representación, del artículo } 20 \text { de } \\
\text { la Ley } 19.234 \text {. }\end{array}$ & Inadmisible \\
\hline 29-07-2009 & $1254-08$ & $\begin{array}{l}\text { Requerimiento de inconstitucionalidad del Presidente del Colegio de } \\
\text { Abogados de Chile A.G., señor Enrique Barros Bourie, en representación de } \\
\text { dicha entidad respecto del texto íntegro del artí́culo } 595 \text { del Código Orgánico } \\
\text { de Tribunales. En subsidio de lo anterior, solicita se declare la inconstitucio- } \\
\text { nalidad del inciso primero del mismo artículo y, en subsidio de esto último, } \\
\text { se declare inconstitucional la expresión «gratuitamente», contenida en la } \\
\text { misma norma legal. }\end{array}$ & Acogido \\
\hline $25-05-2009$ & $1345-09$ & $\begin{array}{l}\text { Pronunciamiento de oficio sobre la inconstitucionalidad de las expresiones: } \\
\text { «Para dar curso a ellos se exigirá que el infractor acompañe el comprobante } \\
\text { de haber pagado la multa», contenidas en el inciso primero del artículo } 171 \\
\text { del Código Sanitario. }\end{array}$ & Acogido \\
\hline $16-04-2009$ & $1173-08$ & $\begin{array}{l}\text { Acción de inconstitucionalidad deducida por Guido Rojas Leal respecto del } \\
\text { inciso tercero del artículo } 474 \text { del Código del Trabajo, que ya fue declarado } \\
\text { inaplicable por este Tribunal Constitucional en sentencias roles } 946 \text { y 968, de } \\
\text { fechas } 1 \text { y } 10 \text { de julio del año 2008, respectivamente. }\end{array}$ & Rechazado \\
\hline $05-06-2007$ & $558-06$ & $\begin{array}{l}\text { Requerimiento de inconstitucionalidad presentado por Fernando Saenger } \\
\text { Gianoni, respecto del inciso tercero del artículo } 416 \text { del Código Procesal } \\
\text { Penal }\end{array}$ & Rechazado \\
\hline $05-06-2007$ & $590-06$ & $\begin{array}{l}\text { Requerimiento de inconstitucionalidad presentado por Fernando Saenger } \\
\text { Gianoni, respecto del inciso tercero del artículo } 416 \text { del Código Procesal } \\
\text { Penal }\end{array}$ & Rechazado \\
\hline 26-03-2007 & $681-06$ & $\begin{array}{l}\text { Proceso de oficio para pronunciarse sobre la inconstitucionalidad del artículo } \\
116 \text { del Código Tributario }\end{array}$ & Acogido \\
\hline
\end{tabular}


Primer criterio. Declaración de inconstitucionalidad de un precepto legal se funda en los principios de supremacía constitucional, concentración de justicia constitucional, igualdad ante la ley y certeza jurídica.

\section{Sentencia 681, considerando sexto}

Que, tal como consta en los antecedentes de la tramitación de la reforma constitucional de agosto de 2005, materializada a través de la Ley 20.050, el sentido de la declaración de inconstitucionalidad de un precepto legal, como nueva atribución conferida al Tribunal Constitucional, tiene directa relación con los principios de supremacía constitucional, de concentración de la justicia constitucional y de igualdad ante la ley.

A juicio de esta Magistratura, la situación sub lite afecta, al mismo tiempo, el principio de certeza jurídica que, tal y como ha sido precisado en su jurisprudencia, constituye un elemento fundamental del Estado de Derecho cuya custodia la Carta encomienda a este órgano de control constitucional.

\section{Sentencia 1.254, considerando vigésimo tercero}

Que, en atención a lo anterior, la jurisdicción constitucional se proyecta así como una de las garantías básicas del Estado constitucional de Derecho y del Régimen Democrático. En efecto, el poder público en todas sus manifestaciones - Estado legislador, Estado administrador y Estado juez- debe someter siempre su quehacer a la Constitución Política de la República. Por su lado, la jurisdicción constitucional debe asegurar que, efectivamente, todas las autoridades públicas sujeten sus actos a las normas, valores y principios constitucionales, de modo que cada una de las funciones estatales se desarrolle dentro de un ámbito correcto y de legítimo ejercicio de la función constitucional que les compete.

\section{Sentencia 1.254, considerando vigesimocuarto}

Que, tal como consta en los antecedentes de la tramitación de la reforma constitucional de agosto de 2005, materializada a través de la Ley 20.050, el sentido de la declaración de inconstitucionalidad de un precepto legal, como nueva atribución conferida al Tribunal Constitucional, tiene directa relación con los principios de supremacía constitucional, de concentración de la justicia constitucional, de igualdad ante la ley y de certeza jurídica, consustanciales a un Estado de Derecho, cuya custodia jurisdiccional la Carta Fundamental encomienda a este órgano de control constitucional.

\section{Sentencia 1.710, considerando cuadragésimo.}

Que los efectos de todas las sentencias del Tribunal Constitucional, especialmente de aquellas que, como en la especie, resuelvan una cuestión de constitucionalidad, deben entenderse a la luz del principio de la supremacía constitucional consagrado en el artículo $6^{\circ}$ de la Constitución, especialmente desde dos perspectivas fundamentales. Por 
una parte, el deber de observancia que a ella deben los titulares e integrantes de los órganos del Estado y, por la otra, su irradiación a toda persona, institución o grupo. El sustento de esta segunda perspectiva es que la comunidad tiene también «el deber de reconocer, respetar y amparar los derechos fundamentales de sus integrantes, sometiéndose tanto a su soberanía y a las autoridades legítimas que la ejerzan, como a los principios democrático y de juridicidad» (Jorge Reyes Riveros, «La Supremacía Constitucional en Chile», en Revista de Derecho de la Universidad Finis Terrae, vol. 9, núm. 11, 2007, p. 110).

\section{Segundo criterio. Declaración de inconstitucionalidad de un precepto legal respeta la labor de los órganos colegisladores y procura eficacia del Estado de Derecho}

\section{Sentencia 681, considerando séptimo}

Que, por otra parte, debe considerarse que la declaración de inconstitucionalidad de un precepto legal declarado previamente inaplicable en casos particulares, en nada vulnera, sino que, por el contrario, refleja y garantiza el necesario respeto hacia la labor de los órganos colegisladores y la plena eficacia de la presunción de constitucionalidad de la ley generada por los órganos legitimados para ello dentro de un Estado democrático. Este principio, reiterado en la jurisprudencia de este Tribunal, constituye una expresión que concreta la separación de funciones del Estado y su asignación a los órganos competentes, que se encuentra expresamente establecida en el artículo 7 , inciso segundo, de la Carta Fundamental.

Asimismo, el control a posteriori de constitucionalidad de la ley, que puede derivar, como en este caso, en la expulsión de un precepto del ordenamiento jurídico positivo, es una competencia que procura regular el correcto funcionamiento y la eficacia del Estado de Derecho, lográndose con ello el fortalecimiento constante de los sistemas de frenos y contrapesos en el actuar de los órganos del Estado en forma compatible con aquella división de funciones prevista en los artículos 6 y 7 de la Constitución.

Sentencia 1.254, considerando vigesimoquinto. Que, por otra parte, debe considerarse que la declaración de inconstitucionalidad de un precepto legal declarado previamente inaplicable en casos particulares, en nada vulnera, sino que, por el contrario, refleja y garantiza el necesario respeto hacia la labor de los órganos colegisladores y la plena eficacia de la presunción de constitucionalidad de la ley generada por los órganos legitimados para ello dentro de un Estado Democrático de Derecho. Este principio, reiterado en la jurisprudencia de este Tribunal, constituye una expresión que concreta la separación de funciones del Estado y su asignación a los órganos competentes, que se encuentra expresamente establecida en el artículo 7, inciso segundo, de la Carta Fundamental. Asimismo, el control a posteriori de constitucionalidad de la ley, que puede derivar, como en este caso, en la expulsión de un precepto del ordenamiento jurídico positivo, es una competencia que procura regular el correcto funcionamiento y la eficacia del 
Estado de Derecho, lográndose con ello el fortalecimiento constante de los sistemas de frenos y contrapesos en el actuar de los órganos del Estado en forma compatible con aquella división de funciones prevista en los artículos 6 y 7 de la Constitución Política de la República, en el marco de un régimen democrático.

Tercer criterio. La declaración de inconstitucionalidad constituye la «última ratio»

\section{Sentencia 1.254, considerando vigesimoprimero}

Que, por lo mismo, resulta evidente que la declaración de inconstitucionalidad constituye el último recurso - la «última ratio»— para asegurar la supremacía constitucional, desde que implica el dejar sin efecto, con carácter derogatorio, un acto emanado del órgano legislativo - expresión de la soberanía popular-, lo que puede eventualmente conllevar un cierto grado de inseguridad jurídica ante el vacío normativo que se produce por la desaparición de un determinado precepto legal que se expulsa del ordenamiento jurídico por ser manifiestamente contrario a la Carta Fundamental.

\section{Cuarto criterio. Consideración respecto de los efectos reales de sus decisiones}

\section{Sentencia 590, considerando vigesimotercero}

Que el intérprete constitucional - guiado, como está, por el propósito de asegurar la primacía efectiva de la Carta Política- no debe desatender los efectos reales que sus decisiones pueden tener para el funcionamiento pleno de las instituciones que gobiernan el Estado de Derecho.

En este contexto, la derogación del precepto legal puede - por la interpretación que se le ha estado otorgando a su inaplicación en causas determinadas- arriesgar la vigencia efectiva del mandato explícito contenido en el artículo 61, inciso segundo, de la Constitución, que impone la actuación judicial previa como requisito de procesabilidad de un parlamentario imputado de un delito de acción privada. De igual forma, puede extender, a casos futuros, la privación del derecho a la acción de la víctima de un eventual ilícito cometido por un parlamentario, como ha acontecido en los procesos por desafuero en que se ha inaplicado el precepto legal que se cuestiona.

\section{Sentencia 1.345, considerando segundo}

En segundo lugar, cabe recordar que este Tribunal ha sostenido que la declaración de inconstitucionalidad de la ley es de tal modo delicada, por los efectos que acarrea, que exige examinar si una decisión de tal envergadura puede acarrear efectos aún más nocivos que los que produce la supervivencia de la norma cuestionada (doctrina desarrollada en sentencia de 5 de junio de 2007, roles acumulados 558 y 590, y también reiterada en la de 16 de abril de 2009, rol 1173). 


\section{Sentencia 1.345, considerando vigésimo}

Que este Tribunal no avizora que el cese de la vigencia de lo dispuesto en el precepto legal en examen pueda producir efectos negativos sobre el sistema institucional que no se hayan analizado. Tal como se ha razonado, el imperio de las resoluciones que dicte el Servicio Nacional de Salud se mantiene sustantivamente inalterado, pudiendo incluso hacerse efectivas mientras se resuelve la gestión judicial en que son reclamadas y tampoco es posible suponer racionalmente que la desaparición de la norma vaya a incentivar litigación frívola o dilatoria que hoy se encuentre desincentivada.

Quinto criterio. La declaración de inconstitucionalidad de un precepto legal no constituye un deber para el Tribunal Constitucional, sino que una facultad

\section{Sentencia 1.254, considerando decimonoveno}

Que la declaración de inconstitucionalidad de un precepto legal declarado previamente inaplicable no constituye un deber para el Tribunal, sino que es una facultad que le corresponderá ejercer en la medida que ninguna interpretación del precepto impugnado permita su ajuste o adecuada sujeción con la Carta Fundamental, tal como se ha sentenciado por esta Judicatura (roles 558, 681 y 1.173).

Sexto criterio. El Tribunal Constitucional debe respetar las apreciaciones de conveniencia y oportunidad del legislador

\section{Sentencia 1.254, considerando vigésimo sexto}

Que, como lo ha señalado esta Magistratura en diversas sentencias, el Tribunal Constitucional es el principal órgano encargado de velar por que la ley no vulnere los límites constitucionales, lo que significa, a la vez, la garantía de cierta esfera de autonomía del legislador, que comprende, básicamente, el conjunto de apreciaciones de conveniencia y oportunidad política que lo llevan a la adopción de una u otra fórmula normativa orgánica. Sólo cuando el Congreso Nacional excede su ámbito de atribuciones, infringiendo los márgenes contemplados en el texto, principios o valores esenciales de la Carta Fundamental, o violenta el proceso de formación de la ley, el Tribunal Constitucional puede intervenir para reparar los vicios de inconstitucionalidad en que éste haya incurrido (véase, entre otros, roles 231, consid. 7; 242, consid. 3; 465, consid. 23; 473, consid. 11; 541, consid. 15; 664/2006, consid. 22; 786 y, más recientemente, 1.361).

Séptimo criterio. Con todo, en caso alguno, la labor del Tribunal Constitucional es legislar

\section{Sentencia 1.254, considerando vigésimo segundo}

Que, en todo caso, la labor de esta Magistratura en modo alguno es la de legislar, sino constatar la irremediable contradicción entre un precepto legal y la Carta Fundamental. 


\section{Sentencia 1.710, considerando cuadragésimo sexto}

Que lo expresado contrasta con una función propositiva o activa que en algunos casos europeos el ordenamiento permite. El Tribunal Constitucional de Chile puede declarar que un precepto jurídico vulnera la Constitución y, en consecuencia, producirse su derogación. O sea, la desaparición del ordenamiento desde la fecha de la publicación en el Diario Oficial de la sentencia que así lo ordena. Sin embargo, una vez adoptada tal resolución, a esta Magistratura no le está dada la atribución de señalar al colegislador cuál debiera ser la norma que reemplace al precepto derogado. Este Tribunal no es colegislador. Y la apreciación que sobre las bondades o carencias de este criterio pudiera formularse, tampoco es de su competencia.

Esta conclusión doctrinaria la obtiene el autor después de efectuar un análisis sobre el nuevo instituto de la inconstitucionalidad en el derecho chileno: «A nuestro juicio la inconstitucionalidad es una sanción específica en el género de las nulidades en Derecho Público, que opera por infracción de la Constitución, y que en cuanto parte integrante de un sistema de garantías configura la jurisdicción constitucional» (Francisco Zúñiga Urbina, "Control de constitucionalidad y sentencia», Cuadernos del Tribunal Constitucional, número 34, año 2006, p. 107).

\section{Octavo criterio: Precepto legal es una unidad de lenguaje que se basta a sí misma}

\section{Sentencia 1.345, considerando cuarto}

Que, por último, las expresiones: «Para dar curso a ellos se exigirá que el infractor acompañe el comprobante de haber pagado la multa», contenidas en el inciso primero del artículo 171 del Código Sanitario constituyen por sí mismas un precepto legal, de aquellos que el numeral 7 del artículo 93 de la Carta Fundamental faculta a este Tribunal para declarar inconstitucional. Como se ha reiterado en fallos anteriores, «una unidad de lenguaje debe ser considerado 'un precepto legal', a la luz del artículo 93 de la Constitución Política, cuando tal lenguaje tenga la aptitud de producir un efecto contrario a la Constitución y más precisamente cuando tenga la aptitud», en el evento de ser declarada inaplicable, «de dejar de producir tal efecto» (sentencia de fecha $16 \mathrm{de}$ enero de 2007 , dictada en la causa rol 626, considerando tercero). Las expresiones que habrán de examinarse, no obstante formar parte de un inciso de un artículo, tienen un efecto propio, independiente del resto del enunciado normativo del que forman parte. En virtud de ellas y por su solo mérito, existe la obligación jurídica para quienes reclaman de una sanción administrativa en sede judicial, de pagar previamente la multa, bajo amenaza de sanción, consistente en no admitirla a tramitación. Ésa es una regla jurídica, cuya constitucionalidad puede evaluarse y, por ende, es un precepto legal, de aquellos a que alude la figura de la inconstitucionalidad. 


\section{Sentencia 1254, considerando decimoprimero}

Que, como ya se ha sentenciado, la expresión precepto legal es equivalente a la de norma jurídica de rango legal, la que puede estar contenida en una parte, en todo un artículo o en varios en que el legislador agrupa las disposiciones de una ley. Así, se ha razonado que «una unidad de lenguaje debe ser considerada un 'precepto legal', a la luz del artículo 93 de la Constitución Política, cuando tal lenguaje tenga la aptitud de producir un efecto contrario a la Constitución» (roles 626/2007 y 944/2008). De este modo, para que una unidad lingüística pueda ser considerada un precepto legal de aquellos a que alude el artículo 93 de la Carta Fundamental, no es necesario que sea completa, sino que se baste a sí misma.

\section{Noveno criterio. Tribunal Constitucional debe buscar interpretación del precepto legal que armonice con la Constitución}

\section{Sentencia 681, considerando octavo}

Que, tal y como lo han reconocido uniformemente la doctrina y la jurisprudencia comparadas, el respeto hacia la labor que desarrolla el legislador obliga al Tribunal Constitucional, en su función de contralor de la constitucionalidad de la ley, a buscar, al menos, alguna interpretación del precepto cuestionado que permita armonizarlo con la Carta Fundamental y sólo en el evento de no ser ello posible, unido a la necesidad de cautelar integralmente la plena vigencia de los principios de supremacía constitucional, igualdad ante la ley y certeza jurídica, resultará procedente y necesaria la declaración de inconstitucionalidad.

\section{Sentencia 59o, considerando séptimo}

Que la llamada interpretación conciliadora de la Constitución deriva de su fuerza normativa, así como de su vinculación y cumplimiento inmediatos, tal como se desprende del artículo $6^{\circ}$, incisos primero y segundo, de la Carta Fundamental.

Un reputado autor (Germán Bidart Campos, El derecho de la Constitución y su fuerza normativa, EDIAR, primera reimpresión, p. 389) asevera que «si es cierto que la fuerza normativa sirve para descalificar transgresiones, su rol fundamental radica en procurar que no haya transgresiones; en que la Constitución se acate, se cumpla y alimente afirmativa y positivamente a todo el mundo jurídico-político. Tal vez resida allí la razón de la aludida obligación judicial de intentar la compatibilización con la Constitución, y sólo después de fracasado ese intento, declarar que una norma o un acto son inconstitucionales».

\section{Sentencia 1.254, considerando decimoctavo}

Que, tal como lo ha señalado reiteradamente esta Magistratura, «el respeto hacia la labor que desarrolla el legislador obliga al Tribunal Constitucional, en su función de 
contralor de la constitucionalidad de la ley, a buscar, al menos, alguna interpretación del precepto cuestionado que permita armonizarlo con la Carta Fundamental y sólo en el evento de no ser ello posible, unido a la necesidad de cautelar integralmente la plena vigencia de los principios de supremacía constitucional, igualdad ante la ley y certeza jurídica, resultará procedente y necesaria la declaración de inconstitucionalidad» (roles 681-2006 y 558-2006). Como ha precisado la doctrina, la denominada «presunción de constitucionalidad impone a quien sostiene que el texto de la ley es inconstitucional, la carga de argumentar convincentemente que se da una incompatibilidad entre la norma que ese texto expresa y el sistema de normas que el texto constitucional consagra» (Víctor Ferreres Comella, Justicia constitucional y democracia, Madrid, CEPC, 1997, p. 141).

\section{Sentencia 2.081, considerando décimo}

Que, desde esta perspectiva, se ha precisado que, para proceder a la declaración de inconstitucionalidad de un precepto legal, es menester que no exista ninguna interpretación posible que permita conciliar dicho precepto con la Carta Fundamental. Esta exigencia se relaciona con la denominada "presunción de constitucionalidad» como criterio hermenéutico aplicable a la decisión de los conflictos constitucionales.

$Y$ es que «el deber de interpretación conforme a la Constitución recibe un crédito casi unánime en la jurisprudencia, al ser considerado como una necesidad intrínseca de cualquier proceso de carácter hermenéutico. Se ha repetido hasta la saciedad que la interpretación conforme tiene su origen en la jurisprudencia de la Corte Suprema Federal de los Estados Unidos, que exigía la interpretación de todas las leyes y los actos de la Administración in harmony with the Constitution» (Figueroa Mejía, Giovanni A., Las sentencias constitucionales atípicas en el Derecho Comparado y en la Acción de Inconstitucionalidad Mexicana, Editorial Porrúa, México, 2011, p. 52).

El Tribunal Constitucional de España ha afirmado, por su parte, que «es necesario apurar las posibilidades de interpretación de los preceptos impugnados conforme a la Constitución y declarar tan sólo la inconstitucionalidad sobrevenida y consiguiente derogación de aquellos cuya incompatibilidad con la misma resulte indudable por ser imposible llevar a cabo tal interpretación» (Sentencia 4/1981, de 2 de febrero). Asimismo, ha expresado que «si existen varios sentidos posibles de una norma (véase disposición), es decir, diversas interpretaciones posibles de la misma, debe prevalecer, a efectos de estimar su constitucionalidad, aquella que resulta ajustada a la Constitución frente a otros posibles sentidos de la norma no conformes con el fundamental» (Sentencia 122/1983, de 16 de diciembre).

\section{Sentencia 2.081, considerando undécimo}

Que, en forma similar a los precedentes de derecho comparado que se han recordado, nuestra Magistratura ha sostenido que: «Tal y como lo han reconocido uniformemente la doctrina y la jurisprudencia comparadas, el respeto hacia la labor que desarrolla el 
legislador obliga al Tribunal Constitucional, en su función de contralor de la constitucionalidad de la ley, a buscar, al menos, alguna interpretación del precepto cuestionado que permita armonizarlo con la Carta Fundamental y sólo en el evento de no ser ello posible, unido a la necesidad de cautelar integralmente la vigencia de los principios de supremacía constitucional, igualdad ante la ley y certeza jurídica, resultará procedente y necesaria la declaración de inconstitucionalidad» (sentencias roles 681, considerando octavo, y 558 y 590 [acumulados], considerando sexto).

\section{Sentencia 2.081, considerando duodécimo}

Que, asimismo, ha afirmado que «es indiscutible que dicha declaración (de inconstitucionalidad) constituye el último recurso para asegurar la supremacía constitucional, desde que implica no sólo la anulación o derogación de un acto emanado de un órgano legislativo - expresión éste [sic] irrecusable de la soberanía popular-, sino que conlleva un cierto grado de inseguridad jurídica ante el vacío normativo que se produce por la desaparición de la norma jurídica naturalmente destinada a regular inmediatamente las conductas, cuyo reemplazo es incierto [...] Una decisión de tal envergadura requiere la ponderación de su conveniencia para el orden constitucional que esta Magistratura debe cautelar. El criterio adecuado para calificarlo es la determinación de las consecuencias de la desaparición del precepto legal. Si deviene en una situación más perjudicial o negativa que la preexistente a su anulación, no resulta conveniente para el interés público y la plena vigencia del Estado de Derecho la derogación de la norma» (sentencia rol 1.710, considerando 22).

Expresado en otros términos, la trascendencia que importa para la integridad del ordenamiento jurídico — ciertamente subordinada al principio de supremacía constitucional-, la declaración de inconstitucionalidad de un precepto legal exige que el juez constitucional pondere adecuadamente los efectos que producirá la expulsión del referido precepto del ordenamiento jurídico, a fin de no provocar una situación más gravosa que aquella que se trata de prever.

\section{Décimo criterio. Sólo cabe declarar la inconstitucionalidad de preceptos legales manifiestamente incompatibles con la Constitución}

\section{Sentencia 2.081, considerando decimocuarto}

Que lo anterior se deriva de la propia naturaleza de control abstracto que importa el examen conducente a determinar la inconstitucionalidad de un precepto legal. En efecto, «el juicio de inconstitucionalidad expresa una comparación abstracta de dos normas de distinto rango, para constatar su manifiesta incompatibilidad. La ilegitimidad constitucional del precepto legal emana de su propio enunciado, sin referencia a una situación singular» (sentencias roles 558 y 590 [acumulados], considerando quinto). 


\section{Undécimo criterio. Diferencias entre la inaplicabilidad y la inconstitucionalidad (concreta y abstracta)}

\section{Sentencia 59o, considerando octavo}

Que, al pronunciarse sobre la inaplicabilidad de un precepto legal, esta Magistratura decide si su aplicación en una determinada gestión judicial resulta contraria a los fines previstos en la Constitución - estimando la relación jurídico-procesal en que incide$y$, por ende, su examen es particular, no se dirige a calificar la legitimidad constitucional del enunciado normativo en abstracto. No le corresponde en ese proceso, entonces, discernir otras interpretaciones de la ley diversas a las que derivan de la forma en que ella se aplica en ese caso concreto. Circunscrita la litis a las pretensiones de las partes, carece el tribunal de facultad para buscar una interpretación de la ley conforme a la Constitución y debe limitarse, como se ha dicho, a establecer si su aplicación específica se atiene o concuerda con aquélla.

\section{Sentencia 1.345, considerando segundo}

Que a propósito de estas reglas constitucionales que enmarcan el quehacer del Tribunal en la materia que nos ocupa, cabe recordar otros dos criterios atingentes que han sido más extensamente explicados en fallos anteriores:

1. El primero es que los exámenes propios de la acción de inaplicabilidad y de inconstitucionalidad, tanto por su regulación constitucional como por los efectos de las respectivas sentencias, son de naturaleza diversa. Así, el primero exige examinar si la concreta aplicación de un precepto legal a un caso determinado - que constituye la gestión pendiente- es capaz de producir en él un resultado contrario a la Constitución, mismo que la sentencia debe evitar, declarando inaplicable la norma para ese solo caso. En cambio, el juicio que ha de emitirse en una acción de inconstitucionalidad exige, por los mismos efectos generales del fallo, un análisis abstracto, siendo procedente acoger la acción sólo si se concluye que el texto legal, en cualquier circunstancia y cualquiera sea la interpretación que de él se haga, infringe la Carta Fundamental. Por lo mismo, este Tribunal ha sostenido que no constituye un deber, sino una facultad declarar inconstitucional un precepto previamente declarado inaplicable (doctrina que puede encontrarse en sentencia de 26 de marzo de 2007 , rol 681, reiterada en la de 16 de abril de 2009, rol 1173).

\section{Sentencia 1.254, considerando vigésimo séptimo}

Que el juicio de inconstitucionalidad expresa una comparación abstracta de dos normas de distinto rango, para constatar su manifiesta incompatibilidad. La ilegitimidad constitucional del precepto legal emana de su propio enunciado, sin referencia a una situación singular. La sentencia estimatoria de inconstitucionalidad, que expulsa el precepto del ordenamiento jurídico, produce efectos generales y derogatorios. En la inapli- 
cabilidad, por el contrario, la decisión jurisdiccional ha de recaer en la conformidad o contrariedad con la Constitución que la aplicación de la norma impugnada puede tener en el caso concreto y no, necesariamente, en su contradicción abstracta y universal con la preceptiva constitucional, por lo que los efectos de la resolución son relativos y conciernen a las partes del juicio o gestión en que inciden.

\section{Sentencia 1.710, considerando vigésimo tercero}

Que en sentencia de 26 de mayo de 2009, en causa rol 1345, que declaró la inconstitucionalidad de determinadas expresiones del artículo 171 del Código Sanitario, esta Magistratura diferenció nítidamente entre la atribución de la cual dispone para resolver sobre la inconstitucionalidad de un precepto legal y aquella que lo habilita para resolver su inaplicabilidad por inconstitucionalidad en una gestión judicial pendiente, sosteniendo que «los exámenes propios de la acción de inaplicabilidad y de inconstitucionalidad, tanto por su regulación constitucional como por sus efectos en las respectivas sentencias, son de naturaleza diversa. Así, el primero exige examinar si la concreta aplicación de un precepto legal a un caso determinado - que constituye la gestión pendiente- es capaz de producir en él un resultado contrario a la Constitución, mismo que la sentencia debe evitar, declarando inaplicable la norma para ese solo caso. En cambio, el juicio que ha de emitirse en una acción de inconstitucionalidad exige, por los mismos efectos generales del fallo, un análisis abstracto, siendo procedente acoger la acción sólo si se concluye que el texto legal, en cualquier circunstancia y cualquiera sea la interpretación que de él se haga, infringe la Carta Fundamental. Por lo mismo, este Tribunal ha sostenido que no constituye un deber, sino una facultad declarar inconstitucional un precepto previamente declarado inaplicable».

\section{Sentencia 1.710, considerando trigésimo primero}

Que, sin embargo, la vinculación entre ambas instituciones adiciona al examen de constitucionalidad la exigencia, no usual en el derecho comparado, de condicionar el control abstracto al control concreto de constitucionalidad, aun cuando, como se ha explicado en el considerando vigesimotercero de esta sentencia, se trata de dos facultades jurisdiccionales de distinta naturaleza. No sólo la inaplicabilidad se refiere a una gestión judicial pendiente, esto es, a un caso concreto que conoce la judicatura, sino que su verificación se produce después de examinar los resultados que tendrá la aplicación del precepto cuestionado. La inconstitucionalidad, por su parte, no se encuentra definida en la Constitución ni en la ley orgánica. Sus contornos son definidos por la atribución que el número 7 del inciso primero del artículo 93 de la Ley Fundamental entrega al Tribunal Constitucional para autorizar su declaración respecto de un precepto legal ya declarado inaplicable, así como por el inciso decimosegundo del mismo artículo, que determina el procedimiento para su tratamiento, y por el efecto derogatorio, compartido con otras declaraciones, que se le atribuye en el tercer inciso del artículo 94 de la 
Constitución. Esas tres reglas determinan que la inconstitucionalidad sea un control abstracto y con efecto erga omnes.

\section{Duodécimo criterio. Precepto legal inaplicado no necesariamente es inconstitucional}

\section{Sentencia 1.254, considerando vigésimo octavo}

Que de lo expuesto se sigue que no existe una relación causal entre ambos juicios - de inaplicabilidad e inconstitucionalidad-, en términos que la inaplicación de un precepto provoque y convoque necesaria y obligatoriamente a una declaración de inconstitucionalidad. Perfectamente una disposición declarada inaplicable puede ser constitucional en abstracto y resultar aplicable en otros casos. Sólo será inconstitucional si ninguna interpretación o posible hipótesis de aplicación de la disposición admite su sujeción a la Carta Fundamental.

\section{Decimotercer criterio. Tribunal Constitucional sólo puede declarar la inconstitucionalidad de un precepto legal ya declarado inaplicable}

\section{Sentencia 1.254, considerando decimotercero}

Que este Tribunal sólo puede declarar inconstitucional un precepto ya declarado inaplicable y, por lo tanto, no puede extender su declaración de inconstitucionalidad más allá de lo resuelto previamente en las sentencias de inaplicabilidad, en todas las cuales, como se ha señalado, sólo se ha decidido acerca de la contrariedad con la Constitución de la obligación de gratuidad contenida en el artículo 595 del Código Orgánico de Tribunales.

\section{Sentencia 1.450, considerando tercero}

Que la norma de la Ley 19.234 que se impugna en el requerimiento deducido a fojas uno no ha sido declarada inaplicable por causa de inconstitucionalidad por este Tribunal, en ejercicio de la atribución que le confiere el numeral 6 del inciso primero del artículo 93 de la Carta Fundamental, circunstancia ésta que constituye un presupuesto procesal para la declaración de inconstitucionalidad de un precepto legal.

\section{Sentencia 1.710, vigésimo noveno}

Que, como ya se ha señalado en los considerandos vigesimoprimero a vigesimotercero de esta sentencia, el constituyente y el legislador orgánico vincularon la declaración de inconstitucionalidad con la de inaplicabilidad, tanto en su relación de existencia como en su contenido. Por una parte, la declaración de inaplicabilidad de un precepto legal es condición sine qua non para que el mismo precepto sea declarado inconstitucional. Por otra parte, la declaración de inconstitucionalidad debe fundarse únicamente en los 
preceptos constitucionales considerados trasgredidos por la sentencia de inaplicabilidad previa que le da sustento.

\section{Decimocuarto criterio. Tribunal Constitucional solo puede declarar la inconstitucionalidad de un precepto legal ya declarado inaplicable en base a las causales en que esta se sustentó}

\section{Sentencia 1.254, considerando decimocuarto}

Que según se desprende de lo preceptuado en el numeral 7 del inciso primero del artículo 93 de la Carta Fundamental, que fija la competencia específica de este Tribunal para resolver las cuestiones de inconstitucionalidad de un precepto legal declarado inaplicable con anterioridad, tal resolución sólo puede considerar las causales en que se sustentó la referida declaración de inaplicabilidad. Ello se desprende de las menciones «declarado inaplicable en conformidad a lo dispuesto en el numeral anterior», las cuales ponen de relevancia que, en un proceso como el de la especie, han de considerarse los vicios de inconstitucionalidad que motivaron específicamente la declaración de inaplicabilidad.

\section{Sentencia 1.710, considerando trigésimo tercero}

Que la declaración de inconstitucionalidad debe recaer sobre los mismos artículos de la Constitución invocados en las resoluciones previas de inaplicabilidad. Sin embargo, debe considerarse que tal infracción ha recaído sobre la aplicación del precepto cuestionado en un caso concreto, en una gestión pendiente, razón por la cual el Tribunal, al ejercer control abstracto de constitucionalidad no puede limitarse a reproducir los mismos razonamientos y análisis efectuados en el análisis de los casos concretos.

\section{Sentencia 1.710, considerando centésimo septuagésimo cuarto}

Que la diferencia descrita exige una distinta fundamentación de una y otra decisión. En efecto, en primer lugar, la Constitución exige congruencia entre las decisiones pasadas y la declaración de inconstitucionalidad, pero no una igualdad de argumentaciones. Cada uno de los exámenes de constitucionalidad de la ley va creando un verdadero sistema donde los controles pasados «despejan» a los futuros. Así, el control preventivo de la ley (artículos 37 y 45 bis de la Ley 17.997) se vincula con la acción de inaplicabilidad (artículos 47 B y 47 F, número 2, de la Ley 17.997) y ésta a la declaración de inconstitucionalidad (artículos 47 R y $47 \mathrm{~V}$ de la Ley 17.997).

\section{Sentencia 1.710, considerando centésimo septuagésimo quinto}

Que, a través de tal mecanismo, la Constitución y la ley orgánica constitucional aludida exigen a este Tribunal ser coherente en la identificación de los vicios en cada una de las etapas sucesivas del control de constitucionalidad de la ley, por cuanto éstos pueden 
presentarse en distintos casos y demostrarse de manera diferente. En todo caso, en sede de inconstitucionalidad el Tribunal no puede ampliar su campo de acción a infracciones constitucionales sobre las que no se ha pronunciado antes. En otras palabras, lo que le está impedido hacer a esta Magistratura es ampliar los vicios que justifican su fallo, pero no así el abundar en las razones que le sirven de apoyo.

\section{Sentencia 1.710, considerando centésimo septuagésimo sexto}

Que, por tanto, aunque se trate del mismo vicio, es posible fundamentar su existencia de un modo distinto a lo declarado en las inaplicabilidades previas. Si el Tribunal estuviera vinculado por las consideraciones que tuvo en el pasado, la facultad del artículo 93, inciso primero, número 7 , constitucional perdería sentido. Ella sería prácticamente automática e indistinguible de las inaplicabilidades.

\section{Sentencia 1.710, considerando centésimo septuagésimo séptimo}

Que, a su vez, el vicio cuya existencia se exige consiste en una contradicción entre el precepto legal que fue declarado inaplicable y la Constitución. Por lo tanto, hay que buscar una identidad entre los preceptos constitucionales que fueron considerados como infringidos en sede de inaplicabilidad y la declaración de inconstitucionalidad; no en la argumentación empleada en aquélla. Ello se demuestra en la forma en que está redactado el artículo $47 \mathrm{~V}$ de la Ley Orgánica Constitucional del Tribunal, que señala: «la declaración de inconstitucionalidad de las normas legales cuestionadas deberá fundarse únicamente en la infracción de el o los preceptos constitucionales que fueron considerados trasgredidos por la sentencia previa de inaplicabilidad que le sirve de sustento».

\section{Sentencia 2.081, considerando decimoquinto}

Que lo que se viene sosteniendo resulta determinante para comprender la diferencia entre el examen conducente a la declaración de inaplicabilidad de un precepto legal de aquel que deriva en la eventual declaración de inconstitucionalidad del mismo.

Tal como este sentenciador ha precisado, «el carácter concreto y no abstracto del requerimiento de inaplicabilidad y de la sentencia de esta Magistratura que lo decide, es de efectos necesariamente acotados a las partes respectivas, debiendo ser desestimada toda pretensión de extenderlos a otras gestiones pendientes, sean iguales o semejantes, porque hacerlo involucraría infundirle las cualidades de abstracción y generalidad que singularizan el pronunciamiento de inconstitucionalidad, erga omnes, de cierta disposición legal» (sentencia rol 1.218, considerando decimotercero).

De allí que, por mucho que el presente pronunciamiento de inconstitucionalidad tenga por antecedente y fundamento las declaraciones de inaplicabilidad recaídas en las sentencias que se han mencionado en el considerando sexto, no puede limitarse simplemente a reproducir los argumentos vertidos en ellas, pues, como se ha dicho, 
lo que en esta oportunidad se examina es la incompatibilidad del precepto legal, en sí mismo, con la Carta Fundamental, independientemente de su aplicación a situaciones concretas como las que involucraron los pronunciamientos expedidos con anterioridad por este Tribunal.

\section{Sentencia 2.80o, considerando segundo}

Que, conforme a lo dispuesto en el artículo 93, inciso primero, número 7, de la Constitución Política de la República, este Tribunal Constitucional tiene la atribución de resolver por la mayoría de los cuatro quintos de sus integrantes en ejercicio, la inconstitucionalidad de un precepto legal declarado previamente inaplicable, en conformidad a lo dispuesto en el numeral 6 de la misma norma.

Y, de acuerdo al artículo 101 de la Ley 17.997, Orgánica Constitucional del Tribunal Constitucional, la declaración de inconstitucionalidad de una norma legal deberá fundarse únicamente en la infracción de el o los preceptos constitucionales que fueron considerados transgredidos por la sentencia previa de inaplicabilidad que le sirve de sustento.

\section{Sentencia 2.80o, considerando tercero}

Que el requirente fundó su acción de inconstitucionalidad en la sentencia previa de esta Magistratura recaída en autos rol 944-07-INA, que acogió el requerimiento de inaplicabilidad impetrado respecto del mismo precepto legal aludido en el considerando primero, fundado únicamente en la vulneración del artículo 19, número 24, de la Constitución.

\section{Sentencia 2.80o, considerando cuarto}

Que, habiéndose procedido a votar el acuerdo de la presente sentencia, estuvieron por acoger el requerimiento, fundados en la infracción al artículo 19, número 24, de la Constitución, los ministros señora Marisol Peña Torres, señores Francisco Fernández Fredes, Iván Aróstica Maldonado, Juan José Romero Guzmán, señora María Luisa Brahm Barril y señores Cristián Letelier Aguilar y Nelson Pozo Silva.

El ministro señor Gonzalo García Pino estuvo por declarar la inconstitucionalidad, pero fundado en consideraciones que no contemplan la infracción del artículo 19, número 24, de la Constitución.

Por su parte, los ministros señores Carlos Carmona Santander (Presidente) y Domingo Hernández Emparanza, estuvieron por rechazar el requerimiento.

\section{Sentencia 2.80o, considerando quinto}

Que, en consecuencia, no se alcanzó el quórum constitucional de cuatro quintos de los ministros en ejercicio del Tribunal, para declarar la inconstitucionalidad del precepto legal impugnado. 
Decimoquinto criterio. La sentencia de inconstitucionalidad, no anula el precepto legal, sino que lo deroga, hacia futuro (derogación sui generis)

\section{Sentencia 1.710, considerando cuadragésimo noveno}

Que, respecto de esta misma materia, la constitucionalista y ex ministra de esta Magistratura, profesora Luz Bulnes Aldunate, ha señalado: «en el proceso de la reforma constitucional se debatió sobre el efecto derogatorio y el de nulidad de la norma declarada inconstitucional. La derogación se diferencia de la nulidad en que se produce al momento de la publicación de la sentencia en el Diario Oficial y no afecta los derechos adquiridos bajo el amparo de la ley inconstitucional; la nulidad en cambio opera con efecto retroactivo y puede afectar a tales derechos. En conformidad con el nuevo artículo 94 la sentencia que declara la inconstitucionalidad de un precepto legal produce la eliminación de la norma del ordenamiento jurídico desde la fecha de la publicación de la misma. Este punto tiene gran importancia, pues de él depende la posibilidad de adquirir y mantener derechos que nacieron al amparo de la ley inconstitucional» (Luz Bulnes Aldunate, «Los recursos de inaplicabilidad y de inconstitucionalidad en la reforma constitucional», en Revista Actualidad Jurídica, núm. 13, enero de 2006, pp. 113-114).

\section{Sentencia 1.710, considerando centésimo sexagésimo séptimo}

Que la doctrina y esta misma sentencia han señalado que esta norma consagra expresamente que las sentencias del Tribunal Constitucional producen efectos ex nunc (Nogueira, Humberto, «El control represivo y abstracto de inconstitucionalidad de leyes en la reforma constitucional de 2005 de las competencias del Tribunal Constitucional y los efectos de sus sentencias», en Francisco Zúñiga (coordinador), Reforma constitucional, Editorial LexisNexis, 2005, p. 615), esto es, produce efectos desde la publicación del fallo «hacia el futuro, no afectando situaciones anteriores producidas al amparo de dicha norma» (p. 608). De esta manera, «ni el Tribunal Constitucional ni el legislador orgánico constitucional podrán dar efecto retroactivo a las sentencias que expulsen de nuestro ordenamiento jurídico disposiciones de rango constitucional» (p. 615).

Este Tribunal Constitucional, por su parte, ha señalado que el hecho de que su sentencia carezca de efectos retroactivos significa que no afecta situaciones acaecidas ni actos realizados con anterioridad a su publicación en el Diario Oficial (Sentencia rol 597 , considerando quinto).

\section{Sentencia 1.710, considerando centésimo sexagésimo octavo}

Que como consecuencia de lo anterior se puede concluir que la irretroactividad se traduce en que la sentencia no puede afectar «situaciones anteriores producidas al amparo de dicha norma» (Nogueira, Humberto, «El control represivo y abstracto de inconstitucionalidad de leyes en la reforma constitucional de 2005 de las competencias del Tribunal Constitucional y los efectos de sus sentencias», p. 467), ni «situaciones acaecidas 
ni actos realizados con anterioridad» (Sentencia rol 597). Así, la sentencia que dicte el Tribunal Constitucional no puede afectar situaciones consolidadas, esto es, nacidas y concluidas bajo el imperio de la o las normas declaradas inconstitucionales.

\section{Sentencia 1.710, considerando centésimo sexagésimo noveno}

Que la regla constitucional señalada resulta de una adecuada consideración entre la seguridad jurídica y la supremacía constitucional. Si bien la supremacía constitucional exigiría la expulsión de todas las normas que pugnen con la Constitución, la seguridad jurídica exige limitar dichos efectos para no afectar a quienes actuaron bajo la expectativa de que el marco legal vigente era regular.

\section{Sentencia 1.710, considerando centésimo septuagésimo}

Que, sin embargo, hay que considerar la naturaleza del contrato de salud que, junto con ser un contrato con elementos de orden público, lo es de tracto sucesivo, no de ejecución instantánea. A diferencia de, por ejemplo, un contrato de compraventa, el contrato de salud origina una relación de permanencia entre la Isapre y el cotizante. De hecho, ésta es la razón por la cual se permiten revisiones en las condiciones del contrato. Las circunstancias fácticas que se tuvieron en consideración al momento de celebrar el contrato pueden cambiar y por ello se admiten ciertas modificaciones (en un marco de razonabilidad y proporcionalidad). Lo mismo autoriza a que, si cambia el marco jurídico aplicable nada menos que por una declaración de inconstitucionalidad, entonces cambien también — hacia futuro- las cláusulas del contrato.

\section{Sentencia 1.710, considerando centésimo septuagésimo primero}

Que, además, debe tenerse presente que la derogación o expulsión de una norma por una declaración de inconstitucionalidad tiene un alcance distinto a una derogación de una norma por el legislador. El Tribunal Constitucional es un órgano que falla de acuerdo a derecho (artículo 92 de la Carta Fundamental); no es un ente de deliberación política que se pronuncie sobre cuestiones de mérito, como los órganos colegisladores. Por ello, su declaración de inconstitucionalidad se basa en que la norma posee un vicio. En cambio, la derogación realizada por el legislador se basa en una nueva evaluación política de la situación. Es una decisión de mérito político. De hecho, es posible hacer un paralelo entre la derogación por inconstitucionalidad efectuada por el Tribunal Constitucional y la derogación efectuada por el legislador, con la invalidación y la revocación de un acto administrativo que efectúa la Administración. Unas situaciones se basan en un vicio y las otras, en cambio, en una valoración de mérito. 
Decimosexto criterio. Declaración de inconstitucionalidad no tiene efectos, en ningún sentido, respecto de preceptos legales similares

\section{Sentencia 1.345, considerando decimonoveno}

Que tanto el Instituto de Salud Pública como el Consejo de Defensa del Estado han hecho ver que el mecanismo en examen es común a otros reclamos judiciales de sanciones administrativas. Ello es efectivo, a la luz de los ejemplos que enumeran en sus presentaciones, pero irrelevante frente a la conclusión a que se ha arribado. En esta causa el Tribunal no está llamado a resolver si son o no constitucionales todas y cada una de las normas que prescriben la obligación de pagar todo o parte de las multas establecidas como sanciones administrativas como condición para reclamar de ellas en sede judicial. Desde luego, no todas ellas exigen el pago del total de lo multado; en ciertos de los otros casos que se nos invocan existen y en otros no normas anexas que permiten el cumplimiento o la suspensión de las sanciones mientras se resuelve el reclamo en sede judicial.

Lo que hemos examinado es la constitucionalidad de una cierta regla contenida en el Código Sanitario. Hemos concluido que ella es contraria a la Carta Fundamental. No hemos juzgado la constitucionalidad de otras normas que guardan con aquélla semejanzas y diferencias, ni tampoco hemos juzgado la conformidad con la Constitución de la figura del solve et repete en general. Nada de ello nos corresponde.

\section{Casos en los cuales el Tribunal Constitucional ha declarado la inconstitucionalidad de un precepto legal}

\section{Artículo 116 del Código Tributario}

A través de la sentencia rol 681, de 23 de junio de 2007, el Tribunal Constitucional declaró la inconstitucionalidad del artículo 116 del Código Tributario.

El cuadro 2 muestra:

a) En un primer plano: Por una parte, las sentencias que declararon la inaplicabilidad del artículo 116 del Código Tributario; y, por la otra, la sentencia que declaró su inconstitucionalidad.

b) En un segundo plano: Por una parte, el precepto legal declarado inaplicable; y, por la otra, el que fue declarado inconstitucional (en ambos casos, con negrilla y subrayado). Adviértase la plena correspondencia entre uno y otro.

\section{Artículo 171 del Código Sanitario}

A través de la sentencia rol 1.345, del 25 de mayo 2009, el Tribunal Constitucional declaró la inconstitucionalidad del precepto legal «Para dar curso a ellos se exigirá que el infractor acompañe el comprobante de haber pagado la multa», contenido en el artículo 171, inciso primero, del Código Sanitario. 


\section{Cuadro 2}

\begin{tabular}{|ll|}
\hline Inaplicabilidad & Inconstitucionalidad \\
\hline $\begin{array}{l}\text { Sentencias } 472,499,502,515,520,525,526,527,528,547, \\
554,555,566,569,574,595,604,605,606,613,614,627,628,\end{array}$ & Sentencia 681 \\
$629,630,635,636,639,640,641,642,647,657$ y 658. & \\
$\begin{array}{l}\text { Artículo } 116 \text { del Código Tributario. El Director Regional podrá } \\
\text { autorizar a funcionarios del Servicio para conocer y fallar reclama- } \\
\text { ciones y denuncias obrando por orden del Director Regional. }\end{array}$ & Artículo 116 del Código Tributario. El Director Regional podrá autori- \\
\hline
\end{tabular}

\section{Cuadro 3}

\begin{tabular}{|c|c|}
\hline Inaplicabilidad & Inconstitucionalidad \\
\hline Sentencias 792, 1061, 1046, 1253, 1262 y 1279 & Sentencia 1345 \\
\hline $\begin{array}{l}\text { Artículo } 171 \text { del Código Sanitario. De las sanciones aplicadas por } \\
\text { el Servicio Nacional de Salud podrá reclamarse ante la justicia } \\
\text { ordinaria civil, dentro de los cinco días hábiles siguientes a la } \\
\text { notificación de la sentencia, reclamo que tramitará en forma } \\
\text { breve y sumaria. Para dar curso a ellos se exigirá que el infractor } \\
\text { acompañe el comprobante de haber pagado la multa. }\end{array}$ & $\begin{array}{l}\text { Artículo } 171 \text { del Código Sanitario. De las sanciones aplicadas por } \\
\text { el Servicio Nacional de Salud podrá reclamarse ante la justicia } \\
\text { ordinaria civil, dentro de los cinco días hábiles siguientes a la } \\
\text { notificación de la sentencia, reclamo que tramitará en forma breve } \\
\text { y sumaria. Para dar curso a ellos se exigirá que el infractor acompañe } \\
\text { el comprobante de haber pagado la multa. }\end{array}$ \\
\hline
\end{tabular}

El cuadro 3 muestra:

a) En un primer plano: Por una parte, las sentencias que declararon la inaplicabilidad de del precepto legal «Para dar curso a ellos se exigirá que el infractor acompañe el comprobante de haber pagado la multa», contenido en el artículo 171, inciso primero, del Código Sanitario; y, por la otra, la sentencia que declaró su inconstitucionalidad.

b) En un segundo plano: Por una parte, el precepto legal declarado inaplicable; y por la otra, el que fue declarado inconstitucional (en ambos casos, con negrilla y subrayado). Adviértase la plena correspondencia entre uno y otro.

Cabe destacar que esta sentencia de inconstitucionalidad contó con el voto en contra de dos ministros (Colombo y Fernández Fredes), quienes plantearon que dicho precepto legal sí admitía una interpretación conforme a la Constitución: que le fuera solicitada a la Administración Sanitaria la suspensión del acto administrativo de sanción, en conformidad a lo preceptuado en el artículo 3, inciso final, de la Ley 19.88o, sobre Bases de los Procedimientos Administrativos, ya que suspendido, no produciría sus efectos y el sancionado no estaría obligado consignar previamente a fin de instar por el control judicial.

\section{Artículo 595 del Código Orgánico de Tribunales}

A través de la sentencia rol 1.254, de 29 de julio de 2009, el Tribunal Constitucional declaró la inconstitucionalidad del precepto legal «gratuitamente», contenido en el artículo 595, inciso primero, del Código Orgánico de Tribunales. 


\section{Cuadro 4}

\begin{tabular}{|c|c|}
\hline Inaplicabilidad & Inconstitucionalidad \\
\hline Sentencias $755,1.138$ y 1.140. & Sentencia 1.254 \\
\hline $\begin{array}{l}\text { Artículo } 595 \text { del Código Orgánico de Tribunales. Corresponde a los } \\
\text { jueces de letras designar cada mes y por turno, entre los no exen- } \\
\text { tos, un abogado que defienda gratuitamente las causas civiles } \\
\text { y otro que defienda las causas del trabajo de las personas que } \\
\text { hubieren obtenido o debieran gozar del mencionado privilegio. } \\
\text { Con todo, cuando las necesidades lo requieran, y el número de } \\
\text { abogados en ejercicio lo permita, la Corte de Apelaciones respec- } \\
\text { tiva podrá disponer que los jueces de letras designen dos o más } \\
\text { abogados en cada turno, estableciendo la forma en que se deban } \\
\text { distribuir las causas entre los abogados designados. } \\
\text { En la misma forma y para los mismos fines harán los jueces de } \\
\text { letras a quienes se refiere el inciso precedente, las correspondien- } \\
\text { tes designaciones de procuradores y receptores. } \\
\text { Cuando alguna persona que goce del privilegio de pobreza no } \\
\text { pueda ser servida por los abogados, procuradores o receptores } \\
\text { nombrados, el juez de letras podrá designar un abogado, un } \\
\text { procurador o un receptor especial que la sirva. } \\
\text { En las comunas o agrupaciones de comunas en donde hubiere } \\
\text { dos o más jueces de letras, hará las designaciones generales } \\
\text { prevenidas en los dos primeros incisos de este artículo, el más } \\
\text { antiguo, y las especiales del inciso precedente el que conociere } \\
\text { del negocio en que han de aplicarse. } \\
\text { Las designaciones generales de abogados, procuradores y re- } \\
\text { ceptores de turno deberán hacerse por las Cortes de Apelaciones } \\
\text { para el territorio jurisdiccional en que éstas tengan su residencia. }\end{array}$ & $\begin{array}{l}\text { Art. } 595 \text { del Código Orgánico de Tribunales. Corresponde a los jue- } \\
\text { ces de letras designar cada mes y por turno, entre los no exentos, } \\
\text { un abogado que defienda gratuitamente las causas civiles y otro } \\
\text { que defienda las causas del trabajo de las personas que hubieren } \\
\text { obtenido o debieran gozar del mencionado privilegio. Con todo, } \\
\text { cuando las necesidades lo requieran, y el número de abogados } \\
\text { en ejercicio lo permita, la Corte de Apelaciones respectiva podrá } \\
\text { disponer que los jueces de letras designen dos o más abogados en } \\
\text { cada turno, estableciendo la forma en que se deban distribuir las } \\
\text { causas entre los abogados designados. } \\
\text { En la misma forma y para los mismos fines harán los jueces de } \\
\text { letras a quienes se refiere el inciso precedente, las correspondien- } \\
\text { tes designaciones de procuradores y receptores. } \\
\text { Cuando alguna persona que goce del privilegio de pobreza no } \\
\text { pueda ser servida por los abogados, procuradores o receptores } \\
\text { nombrados, el juez de letras podrá designar un abogado, un } \\
\text { procurador o un receptor especial que la sirva. } \\
\text { En las comunas o agrupaciones de comunas en donde hubiere } \\
\text { dos o más jueces de letras, hará las designaciones generales } \\
\text { prevenidas en los dos primeros incisos de este artículo, el más } \\
\text { antiguo, y las especiales del inciso precedente el que conociere del } \\
\text { negocio en que han de aplicarse. } \\
\text { Las designaciones generales de abogados, procuradores y } \\
\text { receptores de turno deberán hacerse por las Cortes de Apelaciones } \\
\text { para el territorio jurisdiccional en que éstas tengan su residencia. }\end{array}$ \\
\hline
\end{tabular}

\section{El cuadro 4 muestra:}

a) En un primer plano: Por una parte, las sentencias que declararon la inaplicabilidad del precepto legal "gratuitamente», contenido en el artículo 595, inciso primero, del Código Orgánico de Tribunales; y, por la otra, la sentencia que declaró su inconstitucionalidad.

b) En un segundo plano: Por una parte, el precepto legal declarado inaplicable; y, por la otra, el que fue declarado inconstitucional (en ambos casos, con negrilla y subrayado). Adviértase la plena correspondencia entre uno y otro.

Cabe destacar que esta sentencia de inconstitucionalidad, una vez fue publicada en el Diario Oficial, derogó el señalado precepto legal («gratuitamente»), mas no la carga personal que establece el artículo 595 del Código Orgánico de Tribunales, esto es, el turno de los abogados. Con todo, actualmente, no existe impedimento alguno para que quien asuma dicha carga pueda ejercer las acciones ordinarias pertinentes a fin de que le sean debidamente pagados sus honorarios por el Estado. 


\section{Artículo 38 ter de la Ley 18.933}

A través de la sentencia rol 1.710, de 06 de agosto 2010, el Tribunal Constitucional declaró la inconstitucionalidad de los numerales 1, 2, 3 y 4 del inciso tercer del artículo 38 ter de la Ley 18.933 (de Isapres).

El cuadro 5 muestra:

a) En un primer plano: Por una parte, las sentencias que declararon la inaplicabilidad total o parcial del artículo 38 ter de la Ley 18.933; y, por la otra, la sentencia que declaró la inconstitucionalidad de los numerales 1, 2, 3 y 4 del inciso tercero de dicho artículo.

b) En un segundo plano: Por una parte, el precepto legal declarado inaplicable (en su mayor extensión, por algunas sentencias: todo el artículo 38 ter de la Ley 18.933): y, por la otra, el precepto legal declarado inconstitucional, esto es, los numerales 1, 2, 3 y 4 del inciso tercero de dicho artículo (en ambos casos, con negrilla y subrayado).

\section{Casos especiales}

En los últimos siete años (luego de la última sentencia de inconstitucionalidad) ha habido dos casos especiales: sentencias 1.723 (del 24 de abril de 2011) y 2.800 (del 28 de marzo de 2016).

\section{Caso especial 1: Sentencia rol 1.723}

Se trata de un proceso de inconstitucionalidad, iniciado de oficio, respecto del artículo 2331 del Código Civil, y que a la sazón ya había sido declarado inaplicable en dos oportunidades (sentencias 943 y 1.185).

Conforme consigna la sentencia, el Pleno del Tribunal Constitucional efectuó dos votaciones:

a) La que era de rigor, esto es, a fin de resolver la inconstitucionalidad del precepto legal declarado previamente inaplicable, esto es el artículo 2331 del Código Civil (y en relación a «la infracción de el o los preceptos constitucionales que fueron considerados transgredidos por la sentencia previa de inaplicabilidad»): no hubo quórum para acogerla (4 por acoger y 6 por rechazar).

b) La «indicación del ministro señor Raúl Bertelsen Repetto para declarar inconstitucional únicamente las siguientes partes del artículo 2.331 del Código Civil: el adverbio 'no' que antecede a la forma verbal 'dan' y la frase: 'a menos de probarse daño emergente o lucro cesante, que pueda apreciarse en dinero'»: no hubo quórum para acogerla (4 por acoger y 6 por rechazar).

En el cuadro 6 se resumen las votaciones: La votación en relación a la «indicación» del ministro Bertelsen dio origen a una intensa discusión en el seno del Tribunal Constitucional en cuanto a si éste puede o no declarar la inconstitucionalidad parcial de un precepto legal declarado inaplicable.

Quienes estuvieron en contra de ello, en lo medular, sostuvieron: a) Que tal propuesta importaba «una nueva situación normativa, completamente diferente a las pre- 


\section{Cuadro 5}

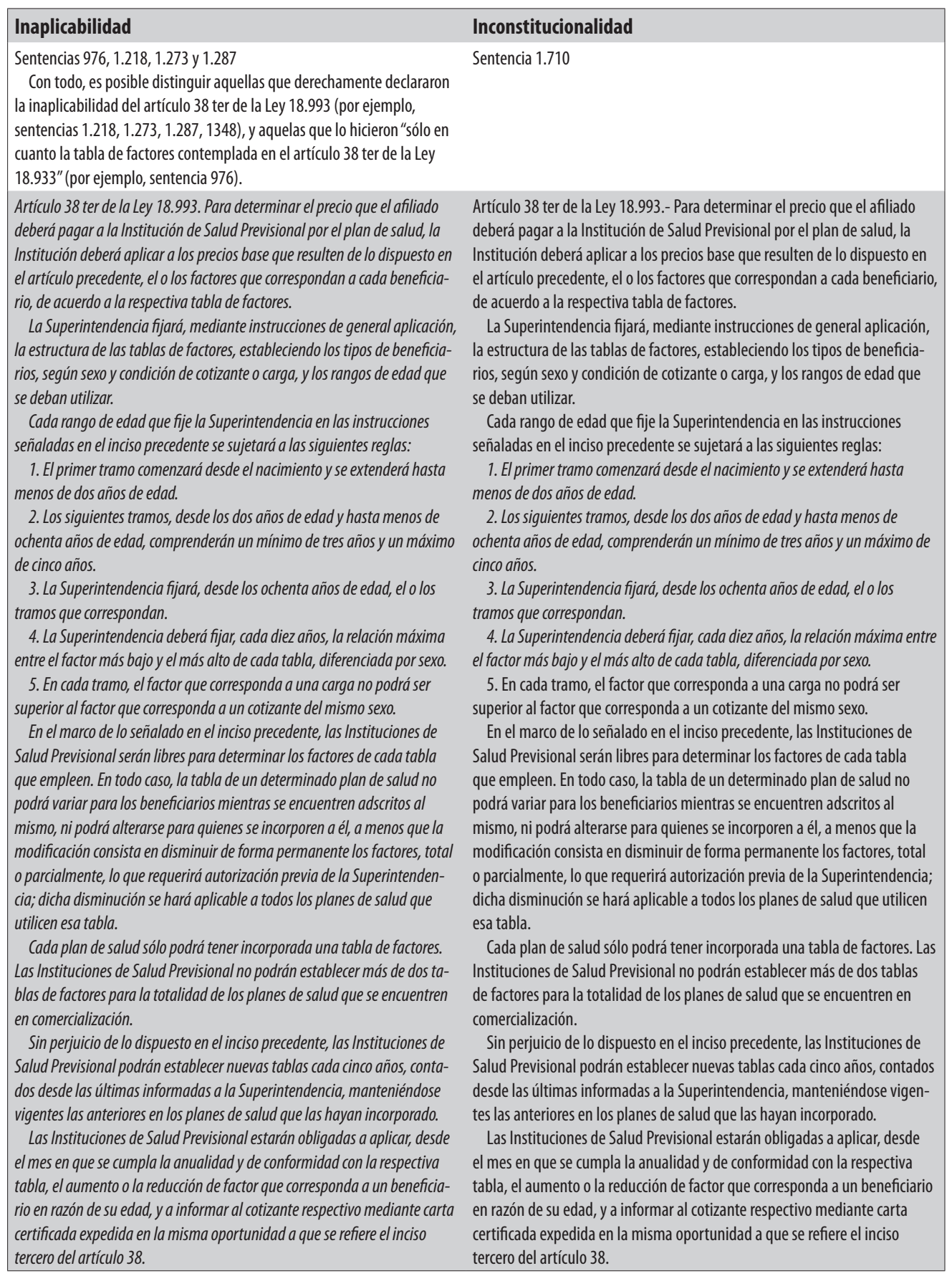




\section{Cuadro 6}

\begin{tabular}{|c|c|c|c|}
\hline Inaplicabilidad & \multicolumn{3}{|l|}{ Inconstitucionalidad } \\
\hline Sentencias 943 y 1.185 & Sentencia 1.723 & & \\
\hline $\begin{array}{l}\text { Artículo 2.331 del Código Civil. Las } \\
\text { imputaciones injuriosas contra el } \\
\text { honor o el crédito de una persona } \\
\text { no dan derecho para demandar una } \\
\text { indemnización pecuniaria, a menos } \\
\text { de probarse daño emergente o lucro } \\
\text { cesante, que pueda apreciarse en } \\
\text { dinero; pero ni aun entonces tendrá }\end{array}$ & $\begin{array}{l}\text { Inconstitucionalidad } \\
\text { total }\end{array}$ & $\begin{array}{l}\text { Artículo } 2.331 \text { del Código Civil. Las imputaciones injurio- } \\
\text { sas contra el honor o el crédito de una persona no dan } \\
\text { derecho para demandar una indemnización pecuniaria, a } \\
\text { menos de probarse daño emergente o lucro cesante, que } \\
\text { pueda apreciarse en dinero; pero ni aun entonces tendrá } \\
\text { lugar la indemnización pecuniaria, si se probare la verdad } \\
\text { de la imputación. }\end{array}$ & $\begin{array}{l}\text { Rechazada } \\
(6 / 4)\end{array}$ \\
\hline $\begin{array}{l}\text { lugar la indemnización pecuniaria, si } \\
\text { se probare la verdad de la imputación. }\end{array}$ & $\begin{array}{l}\text { Inconstitucionalidad } \\
\text { parcial ("indica- } \\
\text { ción" del mimistro } \\
\text { Bertelsen) }\end{array}$ & $\begin{array}{l}\text { Artículo } 2.331 \text { del Código Civil. Las imputaciones } \\
\text { injuriosas contra el honor o el crédito de una persona } \\
\text { no dan derecho para demandar una indemnización } \\
\text { pecuniaria, a menos de probarse daño emergente o lucro } \\
\text { cesante, que pueda apreciarse en dinero; pero ni aun } \\
\text { entonces tendrá lugar la indemnización pecuniaria, si } \\
\text { se probare la verdad de la imputación. } \\
0 \text { si se quiere una nueva redacción del artículo 2.331: } \\
\text { Artículo } 2.331 \text { del Código Civil. Las imputaciones inju- } \\
\text { riosas contra el honor o el crédito de una persona dan } \\
\text { derecho para demandar una indemnización pecuniaria, } \\
\text { pero ni aun entonces tendrá lugar la indemnización } \\
\text { pecuniaria, si se probare la verdad de la imputación. }\end{array}$ & $\begin{array}{l}\text { Rechazada } \\
(6 / 4)\end{array}$ \\
\hline
\end{tabular}

viamente declaradas inaplicables por esta Magistratura, importando en los hechos una nueva redacción y reformulación del precepto legal en cuestión, contenido en el artículo 2331 del Código Civil»; b) Que «la única decisión a que está habilitada esta Magistratura de acuerdo a la normativa constitucional y legal vigente, es a declarar la contravención completa y absoluta entre el precepto legal ya declarado previamente inaplicable y la normativa constitucional aludida»; y c) Que «no le corresponde a esta Magistratura asumir las facultades propias de los colegisladores, sino solamente declarar la contravención absoluta entre un precepto legal determinado y la Carta Fundamental».

Por su parte, quienes estuvieron a favor de ello, en lo medular, sostuvieron que «es evidente, por lo demás, que las inaplicabilidades previas, al operar como fundamento necesario de la inconstitucionalidad de una norma legal, vinculan al Tribunal a no declarar inconstitucional un precepto más allá de las mencionadas declaraciones de inaplicabilidad, pero no impiden, sin embargo, que el Tribunal pueda declarar inconstitucional sólo una parte de un precepto declarado inaplicable. En otras palabras, el Tribunal no puede ir más allá, pero siempre puede auto contenerse».

Adhiero a la tesis de quienes estuvieron en contra. Ello por cuanto:

a) El artículo 93 número 7 de la Constitución otorga al Tribunal Constitucional la atribución de «resolver [...] la inconstitucionalidad de un precepto legal declarado inaplicable». Se trata de una norma que, atendido los singulares y excepcionales efectos que se derivan del ejercicio de la atribución que consulta (derogación de la ley 
por inconstitucional), solo puede ser interpretada restrictivamente. Así, la expresión «resolver» que emplea solo puede ser entendida en su sentido natural y obvio, cual es, acoger o rechazar, de suerte tal que, en mi opinión, al Tribunal Constitucional no le está permitido acoger, en forma parcial, la inconstitucionalidad de un precepto legal declarado inaplicable.

b) A mayor abundamiento, si el Tribunal Constitucional pudiera declarar la inconstitucionalidad, en forma parcial, de un precepto legal declarado inaplicable: i) Esa sentencia de inconstitucionalidad, eventualmente, carecería de fundamento, toda vez que ésta, conforme a lo dispuesto en el artículo 101 de la LOCTC, debe «fundarse únicamente en la infracción de el o los preceptos constitucionales que fueron considerados transgredidos por la sentencia previa de inaplicabilidad que le sirve de sustento», infracción que no necesariamente puede verificarse en relación a la parte del precepto legal (declarado inaplicable) que de esta forma se declararía inconstitucional (la «indicación»); ii) Ello denotaría el reconocimiento de cierta discrecionalidad al Tribunal Constitucional (que por lo pronto queda en evidencia en la expresión «indicación del Ministro...» que la propia sentencia en cuestión emplea), a todas luces, impropia del ejercicio de la jurisdicción; iii) En correspondencia con lo anterior, bien podría sostenerse que el Tribunal Constitucional, en esta hipótesis, más que efectuar una declaración de inconstitucionalidad parcial de un precepto legal declarado inaplicable, está estableciendo una nueva redacción de éste (vale decir, lo que de éste subsista luego de la derogación, igualmente parcial, que produzca la respectiva sentencia una vez sea publicada en el Diario Oficial), vale decir, actuando derechamente como Legislador, máxime si, tal como aconteció en la especie, se entiende que los ministros del Tribunal Constitucional están facultados para someter a votación «indicaciones»; y iv) Finalmente, restaría a la declaración de inconstitucionalidad de un precepto legal el carácter de ultima ratio, atendido el horroris vacuii que consustancialmente produce, y que el propio Tribunal Constitucional le ha reconocido, conforme he tenido oportunidad de apuntar con anterioridad. En efecto, así se corre el riesgo de que la declaración de inconstitucionalidad de un precepto legal, ahora parcial, se trivialice, en tanto se convierta en una suerte de simple modificación o rectificación legislativa a cargo del Tribunal Constitucional.

\section{Caso especial 2: Sentencia rol 2.800}

Se trata de un proceso de inconstitucionalidad, iniciado a través del ejercicio de la acción popular, respecto del precepto legal «a contar de la fecha de publicación del decreto aprobatorio de la cuenta», contenido en el artículo 5 de la Ley 19.800, y que a la sazón ya había sido declarado inaplicable, mediante la sentencia 944, por infracción al artículo 19 número 24 de la Constitución.

En cuanto a la votación, ocho ministros del Tribunal Constitucional estuvieron por declarar inconstitucional el precepto legal en cuestión, de lo que podría estimarse, $a$ prima facie, que se cumplió el quórum exigido al efecto $(4 / 5$ de sus miembros en ejercicio), mas no fue así. ¿La razón? Siete de ellos lo hacían por estimar que aquél infringía el 


\section{Cuadro 7}

\begin{tabular}{|c|c|c|c|c|}
\hline \multicolumn{2}{|l|}{ Inaplicabilidad } & \multicolumn{3}{|l|}{ Inconstitucionalidad } \\
\hline STC 944 & & STC 2800 & & \\
\hline Precepto legal inaplicado & Fundamento & $\begin{array}{l}\text { Precepto legal cuya } \\
\text { inconstitucionalidad se requirió }\end{array}$ & Votación & Fundamento \\
\hline $\begin{array}{l}\text { Art. } 5^{\circ} \text { de la Ley № } 18.900 \text {.- } \\
\text { “Para todos los efectos } \\
\text { legales, a contar de la fecha de } \\
\text { publicación del decreto supremo } \\
\text { aprobatorio de la cuenta, serán } \\
\text { de cargo fiscal las obligaciones }\end{array}$ & $\begin{array}{l}\text { Artículo } 19 \text { No } \\
24 \text { CPR }\end{array}$ & $\begin{array}{l}\text { Art. } 5^{0} \text { de la Ley № } 18.900 \text {.- Para } \\
\text { todos los efectos legales, a contar } \\
\text { de la fecha de publicación del } \\
\text { decreto supremo aprobatorio de } \\
\text { la cuenta, serán de cargo fiscal } \\
\text { las obligaciones de la Caja y de la }\end{array}$ & $\begin{array}{l}7 \text { x acoger (declarar } \\
\text { su inconstituciona- } \\
\text { lidad) }\end{array}$ & Artículo 19 № 24 CPR \\
\hline $\begin{array}{l}\text { de la Caja y de la Asociación } \\
\text { que no alcanzaren a quedar } \\
\text { cubiertas por el producido de } \\
\text { las liquidaciones, debiendo } \\
\text { consultarse los fondos nece- } \\
\text { sarios en el presupuesto de la } \\
\text { Nación, en conformidad a lo } \\
\text { dispuesto en el artículo 21, del } \\
\text { decreto ley 1.263, de 1975. }\end{array}$ & & $\begin{array}{l}\text { Asociación que no alcanzaren a } \\
\text { quedar cubiertas por el producido } \\
\text { de las liquidaciones, debiendo } \\
\text { consultarse los fondos necesarios } \\
\text { en el presupuesto de la Nación, en } \\
\text { conformidad a lo dispuesto en el } \\
\text { artículo 21, del decreto ley } 1.263 \text {, } \\
\text { de } 1975 .\end{array}$ & $\begin{array}{l}1 \times \text { declarar inconsti- } \\
\text { tucionalidad }\end{array}$ & $\begin{array}{l}\text { No } x \text { artículo } 19 \text { No }^{\circ} \\
24 \text { CPR }\end{array}$ \\
\hline
\end{tabular}

artículo 19 número 24 de la Constitución (tal como lo sostuvo la sentencia 944), mas el restante, por estimar que aquél infringía a otro precepto constitucional. En este sentido cabe recordar que la sentencia de inconstitucionalidad de un precepto legal, conforme previene el artículo 101 de la LOCTC, debe «fundarse únicamente en la infracción de el o los preceptos constitucionales que fueron considerados transgredidos por la sentencia previa de inaplicabilidad que le sirve de sustento», en la especie el artículo 19 número 24 de la Constitución, razón por la que solo siete votos eran útiles al efecto.

En el cuadro 7 puede observarse la respectiva votación.

\section{Conclusiones}

A modo de conclusiones, destaco:

a) Desde hace ya siete años (2010-2017) el Tribunal Constitucional no ha dictado sentencia de inconstitucionalidad de un precepto legal, lo cual contrasta con el periodo anterior a éste (2006-2010), en el que lo había hecho con cierta habitualidad (cuatro oportunidades). Estimo que lo anterior se explica por al menos dos razones: a) La adecuación de la LOCTC al texto de la Constitución modificada por la Reforma Constitucional del año 2005, realizada a través de la Ley 20.381; y b) La consolidación de la jurisprudencia del Tribunal Constitucional en relación al ejercicio de esta atribución, de la cual es posible reconocer claros criterios.

b) Entre tales criterios cabe destacar: «La declaración de inconstitucionalidad constituye la «última ratio»» (tercer criterio); «Consideración respecto de los efectos reales de sus decisiones» (cuarto criterio); «La declaración de inconstitucionalidad de un precepto legal no constituye un deber para el Tribunal Constitucional sino que una facul- 
tad» (quinto criterio); «El Tribunal Constitucional debe respetar las apreciaciones de conveniencia y oportunidad del legislador» (sexto criterio); «Con todo, en caso alguno, la labor del Tribunal Constitucional es legislar» (séptimo criterio); «Tribunal Constitucional debe buscar interpretación del precepto legal que armonice con la Constitución» (noveno criterio); «Sólo cabe declarar la inconstitucionalidad de preceptos legales manifiestamente incompatibles con la Constitución» (décimo criterio); «Precepto legal inaplicado no necesariamente es inconstitucional» (duodécimo criterio); «Tribunal Constitucional sólo puede declarar la inconstitucionalidad de un precepto legal ya declarado inaplicable» (decimotercer criterio); «Tribunal Constitucional solo puede declarar la inconstitucionalidad de un precepto legal ya declarado inaplicable en base a las causales en que esta se sustentó» (decimocuarto criterio); $\mathrm{y}$ "Declaración de inconstitucionalidad no tiene efectos, en ningún sentido, respecto de preceptos legales similares» (decimosexto criterio).

c) Asimismo, en estos últimos siete años se han verificado dos casos especiales que reafirman el carácter restrictivo de la declaración de inconstitucionalidad de un precepto legal declarado inaplicable por el Tribunal Constitucional: 1) Sentencia 1723 (2011), que estableció que no es admisible que el Tribunal efectúe la declaración de inconstitucionalidad de un precepto legal declarado inaplicable en forma parcial (en base a «indicaciones» de ministros); y 2) Sentencia 2.80o (2016), que estableció que la declaración de inconstitucionalidad de un precepto legal puede fundarse únicamente en la infracción de el o los preceptos constitucionales que fueron considerados transgredidos por la sentencia previa de inaplicabilidad que le sirve de sustento, de suerte tal que cualquier otra infracción a la Constitución constatada no es útil para los efectos del quórum requerido.

\section{Sobre el autor}

Cristian Román Cordero es abogado y magíster con mención en Derecho Público de la Universidad de Chile. Es también profesor de Derecho Administrativo de la misma universidad. Su correo electrónico es croman@derecho.uchile.cl. 